\title{
Pengaruh Kecerdasan Emosional (Emotional Quotients) dan Kecerdasan Spiritual (Spiritual Quotients) Terhadap Kinerja Pegawai pada Kantor Dinas Perhubungan Provinsi Aceh
}

\author{
RADHIANA * \\ Fakultas Ekonomi, Universitas Serambi Mekkah, \\ Jalan Batoh, Lueng Bata, Kota Banda Aceh, Provinsi Aceh, Indonesia \\ nanaradhiana@gmail.com
}

\section{Article's history:}

Received 12 September 2019; Received in revised form 22 February 2020; Accepted 15 February, 2020; Published 30 February 2020. All rights reserved to the Lembaga Otonom Lembaga Informasi dan Riset Indonesia (KITA INFO dan RISET).

\section{Suggested citation:}

Radhiana, R., 2020. Pengaruh Kecerdasan Emosional (Emotional Quotients) dan Kecerdasan Spiritual (Spiritual Quotients) Terhadap Kinerja Pegawai pada Kantor Dinas Perhubungan Provinsi Aceh. JEMSI (Jurnal Ekonomi, Manajemen, dan Akuntansi), Volume 6 (1): 32-44. DOI: https://doi.org/10.35870/jemsi.v6i1.336.

\begin{abstract}
ABSTRAK:
Penelitian ini bertujuan untuk mengetahui pengaruh kecerdasan emosional dan kecerdasan spiritual terhadap kinerja pegawai kantor Dinas Perhubungan Provinsi Aceh. Populasi dalam penelitian berjumlah 209 orang yang merupakan pegawai kantor Dinas Perhubungan Provinsi Aceh, Sampel dalam penelitian ini inimengunakan rumus Slovin yang berjumlah 68 responden. Metode analisis data menggunakan regresi linier berganda. Hasil dari penelitian variable kecerdasan emosional dan kecerdasan spiritual secara simultan berpengaruh signifikan terhadap kinerja pegawai pada kantor Dinas Perhubungan Provinsi Aceh, karena nilai $F$ hitung sebesar 5,752 lebih besar dari $F$ tabel sebesar 2,352. Variabel kecerdasan Emosional (X1) secara parsial berpengaruh signifikan terhadap kinerja pegawai pada kantor Dinas Perhubungan Provinsi Aceh, karena nilai thitung sebesar 2,863lebih besar dari ttabel sebesar 1,995. Variabel kecerdasan spiritual (X2) secara parsial berpengaruh signifikan terhadap kinerja pegawai pada kantor Dinas Perhubungan provinsi Aceh, karena nilai thitung sebesar 2,569 lebih besar dari ttabel sebesar 1,995. Nilai koefisien korelasi (R) menunjukkan nilai sebesar 0,684 yang menandakan bahwa hubungan antara variabel independen dengan variabel dependen adalah positif karena memiliki nila $R>0,5$. Nilai $R 2$ sebesar 0,734 menunjukkan bahwa hanya sebesar $73,4 \%$ variasi variabel dependen (kinerja pegawai) yang dapat dijelaskan oleh variasi variabel independen (kecerdasan emosional dan kecerdasan spiritual) dalam penelitian ini. Sedangkan sisanya yang sebesar $26,6 \%$ dijelaskan oleh variabel lain yang tidak dimasukkan ke dalam penelitian yang mungkin dapat mempengaruhi kinerja pegawai.
\end{abstract}

Kata Kunci: Kecerdasan Emosional; Kecerdasan Spiritual; Kinerja Pegawai.

JEL Classification: M52; J54.

\section{PENDAHULUAN}

Manusia merupakan sumber daya paling penting dalam usaha organisasi mencapai keberhasilan. Sumber daya manusia ini dapat menunjang organisasi dengan karya, bakat, kreativitas dan dorongan. Sumber daya manusia merupakan aset strategis yang memegang peranan penting di dalam organisasi, betapapun sempurnanya aspek teknologi dan ekonomi tanpa aspek manusia akan sulit untuk mencapai tujuan organisasi, karenanya diperlukan pengelolaan, pemeliharaan, pelatihan dan pengembangan dalam upaya peningkatan kualitas sumber daya manusia pada suatu organisasi atau instansi. Dengan sumber daya manusia yang terlatih dan berkualitas diharap untuk masa yang akan datang dapat memudahkan jalan organisasi dalam pencapaian tujuan organisasi secara efektif dan efisien.

Tujuan sebuah organisasi dapat dilihat dari kinerja yang telah dicapai oleh pegawai, karenanya sebuah organisasi menuntut agar para pegawainya mampu menampilkan kinerja yang optimal karena baik buruknya kinerja yang dicapai oleh pegawai akan berpengaruh pada kinerja dan keberhasilan organisasi secara keseluruhan. Kinerja pegawai adalah hasil kerja atau prestasi dalam bentuk kualitas maupun kuantitas yang sesuai 
dengan tugas dan wewenang yang diberikan selama kurun waktu tertentu dan ukurannya telah ditentukan, meliputi kecepatan, kualitas, keakuratan, ketahanan dalam bekerja dan berkemampuan kerja (Robbins, 2013:89).

Kinerja merupakan masalah yang akan selalu dihadapi oleh pihak manajemen organisasi, karena itu manajemen perlu mengetahui faktor-faktor yang mempengaruhi kinerja pegawai. Banyak faktor-faktor yang dapat mempengaruhi kinerja pegawai salah satu diantaranya, yaitu: Kecerdasan Emosional (Emotional Quotients/EQ) dan Kecerdasan Spiritual (Spiritual Quotient/SQ). kecerdasan Emosional adalah kemampuan pengendalian diri sendiri, semangat dan ketekunan serta kemampuan untuk memotivasi diri sendiri dan bertahan mennghadapi frustasi, kesanggupan untuk mengendalikan dorongan hati dan emosi, tidak melebih lebihkan kesenangan , mengatur suasana hati dan menjaga agar beban stress tidak melumpuhkan kemampuan berfikir untuk membaca perasaan terdalam orang lain (empati) dan berdoa, untuk memelihara hubungan dengan sebaik-baiknya, kemampuan untuk menyelesaikan konflik serta untuk memimpin diri dan lingkungan sekitarnya, Hawari, (2014:155). Faktor-faktor tersebut mempengaruhi pegawai dalam melaksanakan tugas-tugas yang diberikan kepadanya, sehingga hasil akhirnya adalah kinerja pegawai itu sendiri, apakah akan semakin baik atau semakin buruk.

Menyadari tentang pentingnya kecerdasan emosional ini, maka konsep ini sangatlah dibutuhkan baik di lapangan kerja, maupun di semua tempat yang mengharuskan manusia untuk saling berhubungan di dalamnya dengan manusia lain, karena kecerdasan akademis praktis tidak menawarkan persiapan untuk menghadapi gejolak atau kesulitan-kesulitan hidup, bahkan IQ yang tinggipun tidak menjamin kesejahteraan atau kebahagiaan hidup. Sedangkan kecerdasan emosional akan menentukan seberapa baik kita mampu menggunakan keterampilan-keterampilan lain yang kita miliki, termasuk intelektual yang belum terasah Goleman, (2014:53).

Selain faktor Kecerdasan Emosional, kinerja seorang pegawai atau karyawan juga di pengaruhi oleh faktor Kecerdasan Spiritual yang dapat mendukung perkembangan kecerdasan emosional itu sendiri. Kecerdasan Spritual tidak harus berhubungan dengan Agama. Kecerdasan spiritual adalah kecerdasan yang berasal dari dalam hati yang menjadikan kita kreatif ketika kita dihadapkan pada masalah pribadi dan mencoba melihat makna yang terkandung didalamnya serta menyelesaikannya dengan baik agar memperoleh ketenangan dan kedamaian hati, artinya kecerdasan tersebut dapat digunakan untuk menempatkan perilaku serta hidup ke dalam konteks dengan makna yang lebih luas, kecerdasan tersebut nantinya akan menilai jika tindakan ataupun jalan hidup dari seseorang akan lebih bermakna dibandingkan yang lainnya. Kecerdasan Spritual (SQ) sebenarnya merupakan landasan yang digunakan untuk memfungsikan Intelegent Quotient (IQ) serta Emotional Quotient (EQ) dengan efektif ( Zohar \& Marshall , 2001, 12-13).

\section{TINJAUAN KEPUSTAKAAN}

\section{Kinerja Pegawai}

Kinerja merupakan tingkat pencapaian hasil atas pelaksanaan tugas tertentu. Dalam konteks pengembangan sumber daya manusia kinerja seorang pegawai dalam sebuah organisasi sangat dibutuhkan untuk mencapai prestasi kerja bagi pegawai itu sendiri dan juga untuk keberhasilan organisasi. Istilah kinerja berasal dari job performance atau actual performance (prestasi kerja atau prestasi sesungguhnya yang dicapai oleh seseorang), atau juga hasil kerja secara kualitas dan kuantitas yang ingin dicapai oleh seorang pegawai dalam melaksanakan tugasnya sesuai dengan tanggung jawab yang diberikan kepadanya (Mangkunegara, 2013:67).

Menurut Pasolong (2010:176) kinerja merupakan hasil kerja secara kualitas dan kuantitas yang dicapai oleh seseorang dalam melaksanakan fungsinya sesuai dengan tanggung jawab yang diberikan kepadanya. Sedangkan menurut Simanjuntak (2015:221), definisi kinerja adalah tingkat pencapaian hasil atas pelaksanaan tugas tertentu. Kinerja setiap orang dipengaruhi oleh banyak faktor yang dapat digolongkan pada tiga kelompok, yaitu kompetensi individu orang yang bersangkutan, dukungan organisasi, dan dukungan manajemen.

Pendapat lain tentang kinerja, seperti yang dikemukakan oleh Widodo (2013:78) kinerja adalah melakukan suatu kegiatan dan menyempurnakannya sesuai dengan tanggung jawabnya dengan hasil seperti yang di harapkan. Sedangkan menurut Sobandi(2014:176) "Kinerja merupakan sesuatu yang telah dicapai oleh organisasi dalam kurun waktu tertentu, baik yang terkait dengan input, output, outcome, benefit, maupun impact." Hasil kerja yang dicapai oleh aparatur suatu instansi dalam menjalankan tugasnya dalam kurun waktu tertentu, baik yang terkait dengan input, output, outcome, benefit, maupun impact dengan tanggung jawab dapat mempermudah arah penataan organisasi pemerintahan. Adanya hasil kerja yang dicapai oleh aparatur dengan penuh tanggung jawab akan tercapai peningkatan kinerja yang efektif dan efisien. 


\section{Kecerdasan Emosional}

Istilah kecerdasan emosional muncul secara luas pada pertengahan tahun 1990-an. Sebelumnya Gardner (Goleman, 2014:45-51) mengemukakan kecerdasan pada manusia (kecerdasan majemuk). Menurutnya kecerdasan majemuk yang dikemukakan oleh Gardner adalah manisfestasi dari penolakan akan pandangan Intelektual Quotient (IQ). Kecerdasan yang dimaksud adalah kecerdasan antar pribadi dan kecerdasan intrapribadi. Kecerdasan emosional dapat menempatkan emosi individu pada porsi yang tepat, memilah kepuasan dan mengatur suasana hati. Koordinasi suasana hati adalah inti dari hubungan yang baik. Kecerdasan emosional merupakan kemampuan emosi yang meliputi kemampuan untuk mengendalikan diri, memiliki daya tahan ketika menghadapi suatu masalah, mampu mengendalikan impuls, memotivasi diri, mampu mengatur suasana hati, kemampuan berempati dan membina hubungan dengan orang lain.

Kecerdasan emosional sebagai suatu kecerdasan hubungan yang berkaitan dengan kemampuan individu dalam memantau baik emosi dirinya maupun emosi orang lain, dan juga kemampuannya dalam membedakan emosi dirinya dengan emosi orang lain, di mana kemampuan ini digunakan untuk mengarahkan pola pikir dan perilakunya". Sejalan dengan pendapat Agustian (2012:44) mengungkapkan bahwa kecerdasan emosional adalah kemampuan merasakan, memahami dan secara efektif menerapkan daya dan kepekaan emosi sebagai sumber energi, emosi, koneksi dan pengaruh yang manusiawi. Individu yang mampu memahami emosi individu lain, dapat bersikap dan mengambil keputusan dengan tepat tanpa menimbulkan dampak yang merugikan kedua belah pihak. Menurut Goleman (2014:58) mengungkapkan bahwa kecerdasan emosional terdiri dari lima dimensi utama yaitu: (1) mengenali emosi diri, (2) mengelola emosi, (3) memotivasi diri sendiri, (4) mengenali emosi orang lain (5) membina hubungan.

Menurut Robbins (2013:144) kecerdasan emosional merujuk pada satu keanekaragaman keterampilan, kapabilitas, dan kompetensi kognitif yang mempengaruhi kemampuan seseorang untuk berhasil dalam menghadapi tuntutan serta tekanan lingkungan. Dalam kecerdasan antar pribadi yang merupakan kunci menuju pengetahuan diri, ia mencantumkan akses menuju perasaan-perasaan diri seseorang dan kemampuan untuk membedakan perasaan-perasaan tersebut serta memanfaatkannya untuk menuntun tingkah laku. Kecerdasan emosional tidak hanya berfungsi untuk mengendalikan diri, tetapi lebih dari itu juga, mencerminkan dalam mengelola ide, konsep, karya atau produk sehingga hal itu menjadi minat bagi orang banyak (Suharsono, 2014:120). Berdasarkan pendapat para ahli di atas dapat disimpulkan bahwa yang dimaksud kecerdasan emosional adalah kemampuan merasakan dan memahami secara lebih efektif terhadap daya kepekaan emosi yang mencakup kemampuan memotivasi diri sendiri atau orang lain, pengendalian diri, mampu memahami perasaan orang lain dengan efektif, dan mampu mengelola emosi yang dapat digunakan untuk membimbing pikiran untuk mengambil keputusan yang terbaik.

\section{Kecerdasan Spiritual}

Marshall (dalam Paisal, 2010:57) mengatakan kecerdasan spiritual adalah kecerdasan untuk menghadapi dan memecahkan persoalan makna atau nilai (value), yaitu kecerdasan untuk menempatkan perilaku dan hidup kita dalam konteks makna yang lebih luas dan kaya, kecerdasan untuk menilai bahwa tindakan atau jalan hidup seseorang lebih bermakna dibandingkan yang lain. Marshall (dalam Mahmudah, 2015:152) mengatakan bahwa kecerdasan spiritual sangat berkaitan dengan kemampuan seseorang untuk memahami makna hidup dan juga dapat dipakai untuk mengembangkan dan mengoptimalkan kemampuan manusia dalam mengukapkan misteri dirinya. Hidup yang lebih bermakna akan senantiasa melingkupi orang-orang yang mengembangkan kemampuan kecerdasan spiritualnya secara optimal.

Sementara menurut Ramayulis (2014:97) kecerdasan spiritual adalah kecerdasan qalbu yang berhubungan dengan kualitas batin seseorang, kecerdasan ini mengarahkan orang berbuat lebih manusiawi, sehingga dapat menjangkau nilai-nilai luhur yang mungkin belum tersentuh oleh akal pikiran manusia. Roberts (dalam Yudrik, 2013:407) dalam bukunya The Psycology of Ultimate Conrens, kecerdasan spiritual adalah kecerdasan jiwa yang dapat membantu seseorang membangun jiwa secara utuh. Dalam kaitan ini kecerdasan spiritual tidak bergantung pada budaya dan tidak mengikuti nilai-nilai itu sendiri. Menurut Taufik (2015:137) kecerdasan spiritual merupakan kecerdasan yang berkaitan dengan hal-hal yang transenden, hal yang mengatasi waktu dan melampaui kekinian dan pengalaman manusia. Kecerdasan spiritual adalah bagian terpenting dan terdalam dari diri manusia. Selain itu menurut Agustian (2010:47) kecerdasan spiritual adalah kemampuan untuk memberi makna ibadah terhadap setiap perilaku dan kegiatan, melalui langkah- langkah dan pemikiran yang bersifat fitrah, menuju manusia yang seutuhnya dan memiliki pola pemikiran (integralistik), serta berprinsip. Dapat disimpulkan bahwa kecerdasan spiritual adalah kemampuan yang dimiliki seseorang untuk menghadapi dan memecahkan berbagai makna, kontrol diri, dan menggunakan hati nuraninya dalam kehidupan serta kemampuan 
memberi makna nilai ibadah kehidupannya serta berprinsip. Kecerdasan spiritual adalah kemampuan seseorang untuk mendengarkan hati nuraninya, baik buruk dan rasa moral dalam caranya menempatkan diri dalam pergaulan

\section{METODE PENELITIAN}

\section{Populasi dan Penarikan Sampel}

Populasi dalam penelitian adalah para pegawai pada Dinas Perhubungan Provinsi Aceh yang berjumlah 209 orang. Sedangkan sampel penelitian adalah objek yang diteliti dan dianggap mewakili seluruh populasi. Penarikan sampel dilakukan dengan menggunakan rumus Slovin. Rumus sederhana dalam menentukan sampel dijelaskan sebagai berikut yaitu( Notoatmodjo (2010:115) :

Rumus: $n=\mathrm{N} /\left(1+\mathrm{N} \mathrm{e}^{\wedge} 2\right)$

Dimana:

$n$ : Ukuran Sampel

$\mathrm{N}$ : Ukuran Populasi

e : Prosentase kelonggaran ketelitian karena kesalahan pengambilan sampel.

Dari jumlah populasi tersebut dengan menggunakan rumus Slovin sebesar 10\% maka jumlah minimum yang diambil sebesar:

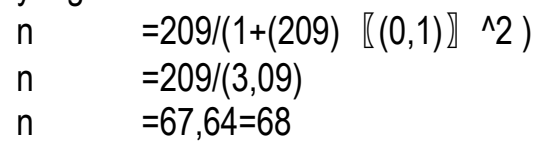

Berdasarkan pengertian populasi dan sampel, maka yang menjadi sampel dalam penelitian ini berjumlah 68 responden. Mengingat jumlah populasi yang diketahui lebih dari 100, maka penulis menggunakan rumus Slovin sebagai alat untuk menghitung ukuran sampel dalam penelitian ini.

\section{Peralatan Analisis Data}

Menurut Sugiyono (2012:277) peralatan analisis data dalam penelitian ini adalah analisis regresi linear berganda. Analisis regresi linear berganda digunakan untuk menaksir keadaan naik turunnya viariabel dependen, bila dua atau lebih variabel dependen sebagai faktor prediktor dimanipulasi (dinaik turunkan nilainya). Dalam penelitian ini tujuan analisis regresi linear berganda adalah untuk menguji seberapa besar pengaruh antara variabel bebas dan variabel terikat yaitu antara Kecerdasan Emosional (X1), Kecerdasan Spiritual (X2), dan Kinerja Pegawai $(Y)$. Persamaan garis regresi menggunakan rumus

$$
Y=\beta o+\beta_{1} X_{1}+\beta_{2} X_{2}+\varepsilon
$$

$$
\begin{array}{ll}
Y & =\text { Kinerja Pegawai } \\
\beta_{0} & =\text { Konstanta } \\
X_{1} & =\text { Kecerdasan Emosional } \\
X_{2} & =\text { Kecerdasan Spiritual } \\
\beta_{1} \beta_{2} & =\text { Koefesien Korelasi } \\
\varepsilon & =\text { Faktor penganggu diluar model }
\end{array}
$$

\section{Uji Statistik t}

Uji t dilakukan untuk menguji pengaruh variabel independen yaitu Kecerdasan Emosional dan Kecerdasan Spiritual secara parsial terhadap variabel dependen yaitu Kinerja (Priyatno, 2012:58). Kriteria pengujian hipotesis secara parsial adalah sebagai berikut:

$\mathrm{Ho}=$ Kecerdasan emosional dan kecerdasan spiritual tidak berpengaruh signifikan terhadap kinerja pegawai pada kantor Dinas Perhubungan Provinsi Aceh

$\mathrm{Ha}=$ Kecerdasan emosional dan kecerdasan spiritual berpengaruh signifikan terhadap kinerja pegawai pada kantor Dinas Perhubungan Provinsi Aceh

Kriteria pengambilan keputusan untuk uji $t$ (uji parsial) ada thitung $\leq t$ tabel atau $-t$ hitung $\geq-t$ tabel pada $a=$ $5 \%$ jadi Ho diterima dan $t$ hitung $>$ tabel atau $-t$ hitung $<-t$ tabel pada $\alpha=5 \%$ jadi Ho ditolak (Priyatno, 2012:59). 


\section{Uji Statistik F}

Uji $F$ digunakan untuk menguji pengaruh variabel independen secara bersama-sama terhadap variabel dependen. Pembuktian dilakukan dengan cara membandingkan Ftabel dengan nilai Fhitung. Jika Fhitung lebih besar dari pada Ftabel. maka keputusannya menolak hipotesis nol $(\mathrm{Ho})$ dan menerima hipotesis alternatif $(\mathrm{Ha})$ (Priyatno, 2012:56). Model analisis yang digunakan dalam uji $F$ ini adalah:

$\mathrm{Ha}=$ Kecerdasan emosional dan kecerdasan spiritual secara bersama-sama berpengaruh signifikan terhadap kinerja pegawai pada kantor Dinas Perhubungan Provinsi Aceh

$\mathrm{Ho}=$ Tidak ada pengaruh signifikan antara kecerdasan emosional dan kecerdasan spiritual secara bersama-sama terhadap kinerja pegawai pada kantor Dinas Perhubungan Provinsi Aceh

Kriteria pengambilan keputusan Uji F adalah Fhitung $\leq$ Ftabel pada $a=5 \%$ jadi Ho diterima dan Fhitung $>$ Ftabel pada $\alpha=5 \%$ jadi Ho ditolak (Priyatno, 2012:57).

\section{HASIL PENELITIAN DAN PEMBAHASAN}

\section{Uji Validitas dan Reliabilitas}

\section{Hasil Uji Validitas}

Di dalam penelitian ini pengujian validitas data dilakukan secara statistik, yaitu dengan menggunakan uji pearson product-moment Coeffisient of Correlation dengan bantuan software komputer melalui program Statistic Packege for Perhubungan Sciensin (SPSS) IBM 22. Berdasarkan hasil pengolahan data (terlampir) seluruh item pertanyaan dinyakatan valid karena memiliki nilai signifikansi dibawah $5 \%$, yaitu dengan membandingkan seluruh pertanyaan $r$ hitung dengan $r$ tabel produck moment. Apabila $r$ hitung $>r$ tabel maka item pertanyaan dinyatakan valid. Sehingga pertanyaan-pertanyaan tersebut adalah signifikan atau konsisten, artinya data yang diperoleh dapat dipergunakan untuk penelitian. Mengenai hasil pengujian validitas dapat dilihat pada tabel berikut ini.

Tabel 1. Hasil Uji Validitas

\begin{tabular}{|c|c|c|c|c|c|}
\hline No & Variabel & $\begin{array}{c}\text { Butir } \\
\text { Pertanyaan }\end{array}$ & Nilai $r$ hitung & $\begin{array}{c}\text { Nilai } r \text { tabel } \\
(\mathrm{N}=68)\end{array}$ & Keterangan \\
\hline & & A 1 & 0,357 & & \\
& Kecerdasan & A 2 & 0,446 & \multirow{2}{*}{ Valid } \\
& Emosional & A 3 & 0,549 & & \\
& $\left(\mathrm{X}_{1}\right)$ & A 4 & 0,539 & & \\
& & A 5 & 0,249 & & \\
\hline
\end{tabular}

Tabel 2. Hasil Uji Validitas

\begin{tabular}{|c|c|c|c|c|c|}
\hline No & Variabel & $\begin{array}{c}\text { Butir } \\
\text { Pertanyaan }\end{array}$ & Nilai $r$ hitung & $\begin{array}{c}\text { Nilai } r \text { tabel } \\
(\mathrm{N}=688)\end{array}$ & Keterangan \\
\hline 1 & $\begin{array}{c}\text { Kecerdasan } \\
\text { Emosional } \\
\left(X_{1}\right)\end{array}$ & $\begin{array}{l}\text { A 1 } \\
\text { A2 } \\
\text { A 3 } \\
\text { A 4 } \\
\text { A5 }\end{array}$ & $\begin{array}{l}0,357 \\
0,446 \\
0,549 \\
0,539 \\
0,249\end{array}$ & 0,235 & Valid \\
\hline 2 & $\begin{array}{l}\text { Kecerdasan Spiritual } \\
\qquad\left(X_{2}\right)\end{array}$ & $\begin{array}{l}\text { C } 1 \\
\text { C } 2 \\
\text { C } 3 \\
\text { C } 4 \\
\text { C } 5 \\
\text { C } 6 \\
\text { C } 7\end{array}$ & $\begin{array}{l}0,590 \\
0,444 \\
0,260 \\
0,395 \\
0,500 \\
0,526 \\
0,245\end{array}$ & 0,235 & Valid \\
\hline 3 & $\begin{array}{c}\text { Kinerja Pegawai } \\
(Y)\end{array}$ & $\begin{array}{l}\text { D } 1 \\
\text { D } 2 \\
\text { D } 3 \\
\text { D } 4 \\
\text { D } 5 \\
\text { D } 6 \\
\end{array}$ & $\begin{array}{l}0,361 \\
0,267 \\
0,309 \\
0,433 \\
0,466 \\
0,506\end{array}$ & 0,235 & Valid \\
\hline
\end{tabular}

Sumber: data primer yang diolah, 2019. 
Berdasarkan Tabel Hasil Uji Validitas diatas menunjukkah besarnya koefisien korelasi antara tiap-tiap item dengan total item untuk instrumen Kecerdasan Emosional, Kecerdasan Spiritual dan Kinerja Pegawai. Adapun besarnya koefisien dari item untuk instrumen Kecerdasan Emosional adalah berkisar antara 0,249-0,549, koefisien dari item untuk instrumen Kecerdasan Spiritual adalah berkisar antara 0,245-0,590, sedangkan instrumen Kinerja Pegawai menunjukkan angka berkisar 0,267-0,506. Karena nilai r $\urcorner$ hitung dari variabel-variabel tersebut lebih besar dari nilai rtabel yaitu 0,235 . Sehingga dapat diartikan bahwa seluruh pertanyaan yang berhubungan dengan keempat variabel tersebut (Kecerdasan Emosional, Kecerdasan Spiritual dan Kinerja Pegawai) dinyatakan valid.

\section{Hasil Pengujian Reliabilitas}

Pengujian realibilitas digunakan untuk mengukur apakah alat pengumpulan data telah menunjukkah tingkat ketepatan, keakuratan atau konsentrasi alat tersebut dalam mengungkapkan gejala tertentu dari sekelompok individual. Untuk menguji keadaan kuisioner yang digunakan, maka penelitian ini menggunakan uji realibilitas. Analisis yang digunakan untuk mentafsirkan korelasi antara skala yang dibuat dengan skala variabel yang ada. Hasil uji realibilitas untuk variabel dependen dan variabel independen juga menunjukkan hasil yang reliabel. Nilai cronbach Alpha yang dihasilkan > 0.5, sehingga variabel Kecerdasan Emosional, Kecerdasan Spiritual dan Kinerja Pegawai yang digunakan dinyatakan realibel. Berikut ini adalah hasil dari output komputer program IBM Statistic Packege for Perhubungan Sciensin (SPSS) 22 mengenai uji reliabilitas untuk instrumen Kecerdasan Emosional, Kecerdasan Intelektual, Kecerdasan Spiritual dan Kinerja Pegawai.

Tabel 3. Pengujian Reliabilitas Butir-Butir Variabel Penelitian

\begin{tabular}{|c|c|c|c|}
\hline Variabel & $\begin{array}{c}\text { Alpha Cronbach } \\
\text { Hitung }\end{array}$ & $\begin{array}{c}\text { Alpha Cronbach } \\
\text { yang disyaratkan }\end{array}$ & Keterangan \\
\hline $\begin{array}{c}\text { Kecerdasan Emosional } \\
\left(X_{1}\right)\end{array}$ & 0,567 & 0,50 & Reliabel \\
\hline $\begin{array}{c}\text { Kecerdasan Spiritual } \\
\left(\mathrm{X}_{2}\right)\end{array}$ & 0,614 & 0,50 & Reliabel \\
\hline $\begin{array}{c}\text { Kinerja Pegawai } \\
(\mathrm{Y})\end{array}$ & 0,539 & 0,50 & Reliabel \\
\hline
\end{tabular}

Sumber: data primer yang diolah, 2019

Berdasarkan Tabel pengujian Reliabilitas butir-butir variable penelitian diatas dapat diketahui bahwa hasil perhitungan Alpha Cronbach adalah 0,567 untuk instrumen pengukuran Kecerdasan Emosional, nilai dari instrumen Kecerdasan Spiritual memiliki bobot adalah 0,614, sedangkan nilai dari instrumen Kinerja Pegawai memiliki bobot adalah 0,539. Dengan demikian dapat di ambil kesimpulan bahwa nilai total dari masing-masing empat variabel tersebut adalah reliabel.

\section{Hasil Uji Asumsi Klasik}

Secara teori uji asumsi klasik dilakukan sebelum Uji Regresi (karena Model regresi harus terlebih dahulu Iolos Asumsi Klasik) namun dalam prakteknya asumsi klasik dilakukan sekaligus dalam uji regresi. Dalam pengujian ini ada 4 (empat) jenis asumsi klasik yang akan digunakan, yaitu :

1. Hasil Uji Normalitas Data

Uji normalitas bertujuan untuk menguji apakah dalam model regresi variabel pengganggu atau residual memiliki distribusi normal atau tidak, dengan membuat hipotesis sebagai berikut:

Ho : data residual terdistribusi normal,

$\mathrm{Ha}$ : data residual terdistribusi tidak normal.

Pengujian normalitas dapat digunakan untuk mendeteksi apakah residual berdistribusi normal atau tidak, yaitu dengan cara analisis grafik. Analisis grafik dapat digunakan dengan dua alat, yaitu grafik histogram dan grafik P-P Plot. Data yang baik adalah data yang memiliki pola distribusi normal. Pada grafik histogram, data yang mengikuti atau mendekati distribusi normal adalah distribusi data dengan bentuk lonceng. Pada grafik P-P Plot, sebuah data dikatakan berdistribusi normal apabila titik-titik datanya tidak menceng ke kiri atau ke kanan, melainkan menyebar di sekitar garis diagonal. 


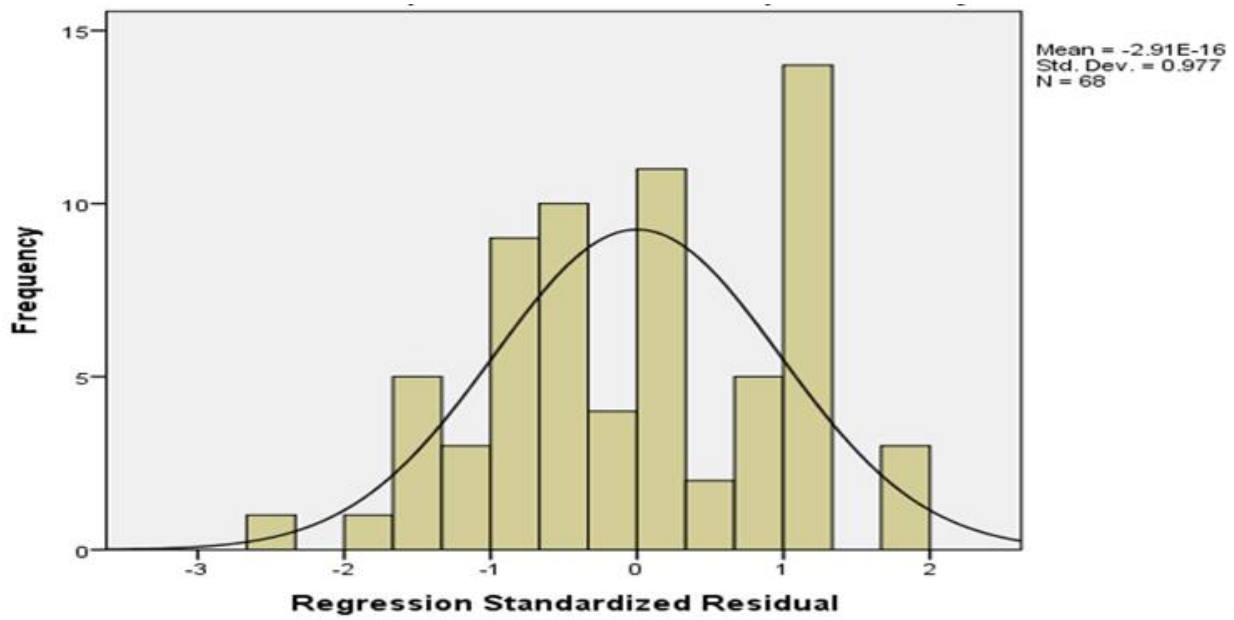

Gambar 1. Grafik Histrogram

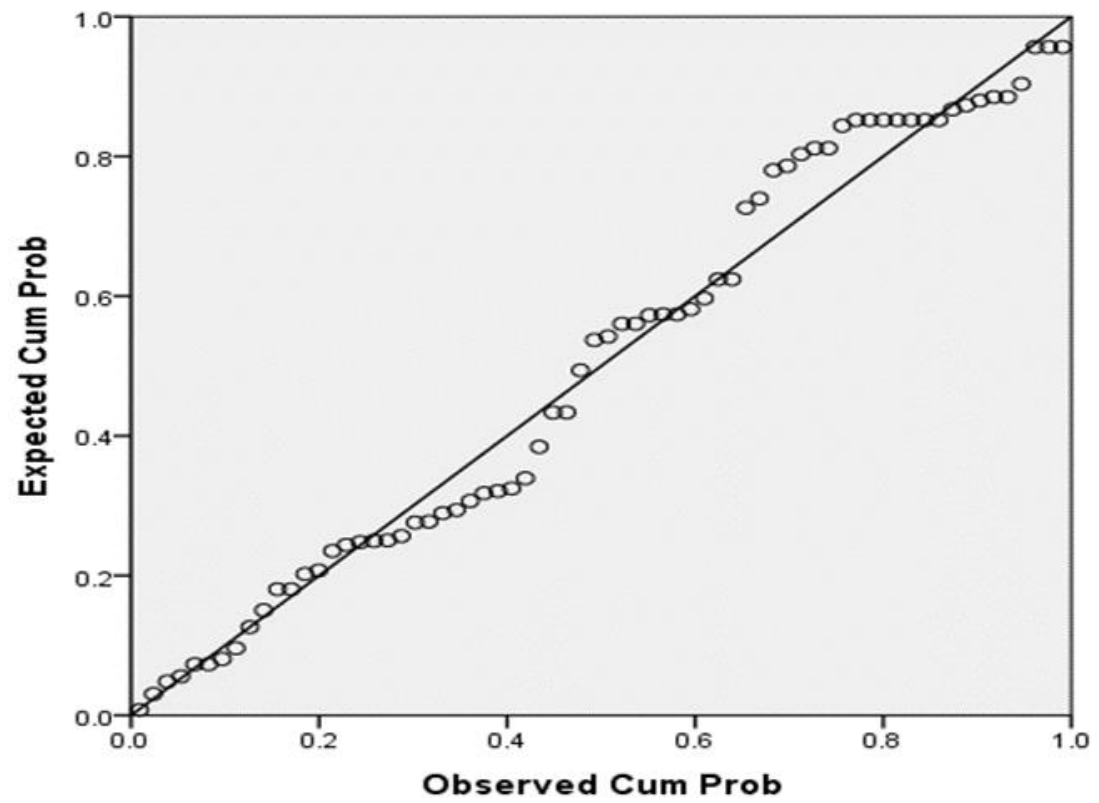

Gambar 2. Normalitas Probability Plot Hasil Pengujian Normalitas Data

Dengan melihat tampilan grafik histogram, penulis melihat bahwa gambar histogram telah berbentuk lonceng, artinya menunjukkan bahwa data terdistribusi secara normal. Pada grafik P-P Plot terlihat bahwa titik-titik menyebar di sekitar garis diagonalnya sehingga dapat diartikan data yang digunakan dalam penelitian ini terdistribusi secara normal.

\section{Hasil Uji Autokorelasi}

Uji autokorelasi berguna untuk mengetahui apakah dalam sebuah model regresi linear berganda terdapat hubungan yang kuat baik positif maupun negatif antara data yang ada pada variabel-variabel penelitian. Jika terjadi korelasi, maka hal tersebut dinamakan adanya permasalahan autokorelasi. Untuk melihat ada tidaknya autokorelasi maka menggunakan uji Durbin-Watson, berikut hipotesis yang akan diuji:

a. Jika DW dibawah -2 berarti adanya autokorelasi positif

b. Jika DW berada diantara -2 sampai +2 berarti tidak ada autokorelasi

c. Jika DW diatas +2 berarti ada autokorelasi 
Tabel 4. Autokorelasi

Model Summaryb

\begin{tabular}{|l|r|r|r|r|r|}
\hline Model & \multicolumn{1}{|c|}{$\mathrm{R}$} & \multicolumn{1}{|c|}{$\mathrm{R}$ Square } & \multicolumn{1}{c|}{$\begin{array}{c}\text { Adjusted } \mathrm{R} \\
\text { Square }\end{array}$} & $\begin{array}{c}\text { Std. Error of the } \\
\text { Estimate }\end{array}$ & Durbin-Watson \\
\hline 1 & $.684^{\mathrm{a}}$ & .734 & .411 & 1.165 & 1.113 \\
\hline
\end{tabular}

a. Predictors: (Constant), Kecerdasan Spiritual, Kecerdasan Emosional

b. Dependent Variable: Kinerja Pegawai

Sumber: data primer yang diolah, 2019

Bedasarkan Tabel Autokorelasi tersebut diatas dapat diketahui nilai Durbin-Watson sebesar 1,113. Sehingga Durbin-Watson berada dibawah -2. Maka dapat disimpulkan bahwa dalam penelitian ini adanya autokorelasi positif autokorelasi. Artinya bahwa variabel independent dalam penelitian ini positif atau tidak terpengaruhi oleh variabel pengganggu.

\section{Hasil Uji Multikolinearitas}

Menurut Ghozali (2005:91),“Uji multikolinearitas dilakukan untuk menguji apakah pada model regresi ditemukan adanya korelasi antar variabel bebas (independen)". Adanya gejala multikolinearitas dapat dilihat dari tolerance value atau nilai Variance Inflation Factor (VIF). Batas tolerance value adalah 0,1 dan batas VIF adalah 10. Apabila tolerance value $<0,1$ atau $\mathrm{VIF}>10=$ terjadi multikolinearitas. Apabila tolerance value $>0,1$ atau VIF $<10=$ tidak terjadi multikolinearitas. Hasil pengujian terhadap multikolinearitas pada penelitian ini dapat dilihat pada Tabel Hasil Uji Multikolineritas di bawah ini.

Tabel 5. Hasil Uji Multikolineritas

\section{Coefficients ${ }^{\mathrm{a}}$}

\begin{tabular}{|c|c|c|c|c|c|c|c|}
\hline \multirow[t]{2}{*}{ Model } & \multicolumn{2}{|c|}{$\begin{array}{c}\text { Unstandardized } \\
\text { Coefficients }\end{array}$} & $\begin{array}{c}\text { Standardized } \\
\text { Coefficients }\end{array}$ & \multirow[t]{2}{*}{$\mathrm{t}$} & \multirow[t]{2}{*}{ Sig. } & \multicolumn{2}{|c|}{ Collinearity Statistics } \\
\hline & B & Std. Error & Beta & & & Tolerance & VIF \\
\hline (Constant) & 19.018 & 2.918 & & 6.518 & .000 & & \\
\hline $\begin{array}{l}\text { Kecerdasan } \\
\text { Emosional }\end{array}$ & .252 & .120 & .157 & 2.863 & .211 & .972 & 1.029 \\
\hline Kecerdasan Spiritual & .269 & .121 & .070 & 2.569 & .571 & .985 & 1.015 \\
\hline
\end{tabular}

a. Dependent Variable: Kinerja Pegawai

Sumber: data primer yang diolah, 2019

Berdasarkan Tabel hasil uji Multikolineritas diatas dapat dilihat bahwa tidak ada variabel bebas memiliki nilai VIF lebih besar dari 10 dan tidak ada yang memiliki tolerance value lebih kecil dari 0,1. Jadi dapat disimpulkan bahwa penelitian ini bebas dari adanya multikolinearitas. Dari hasil analisis, didapat nilai VIF variabel Kecerdasan Emosional adalah 1,029 $(<10)$ dan nilai tolerance sebesar 0,972 $(>0,1)$, nilai VIF variabel Kecerdasan Spiritual adalah $1,015(<10)$ dan nilai tolerance sebesar 0,985 $(>0,1)$. Dengan demikian dapat disimpulkan bahwa variabel bebas yang dipakai dalam penelitian ini lolos uji gejala multikolinearitas.

\section{Hasil Uji Heteroskedastisitas}

Menurut Ghozali (2005:105), "Uji Heteroskedastisitas bertujuan menguji apakah dalam model regresi terjadi ketidaksamaan variance dari residual satu pengamatan ke pengamatan yang lain. Jika variance dari residual satu pengamatan ke pengamatan yang lain tetap, maka disebut Homoskedastisitas dan jika berbeda disebut Heteroskedastisitas. Model regresi yang baik adalah yang Homoskedastisitas atau tidak terjadi Heteroskedastisitas. Kebanyakan data crosssection mengandung situasi heteroskedastisitas karena data ini menghimpun data yang mewakili berbagai ukuran (kecil,sedang,dan besar)".

Pengujian heteroskedastisitas dapat dilakukan dengan uji grafik dengan melihat grafik scatterplot yaitu dengan cara melihat titik-titik penyebaran pada grafik dan uji glejser, dengan cara meregres seluruh variabel independen dengan nilai absolute residual (absut) sebagai variabel dependennya. Perumusan hipotesis adalah :

HO: tidak ada heteroskedastisitas,

$\mathrm{H}$ a: ada heteroskedastisitas.

Jika signifikan $<0,05$ maka Ha diterima (ada heteroskedastisitas) dan jika signifikan $>0,05$ maka $\mathrm{H} 0$ diterima (tidak ada heteroskedastisitas). 


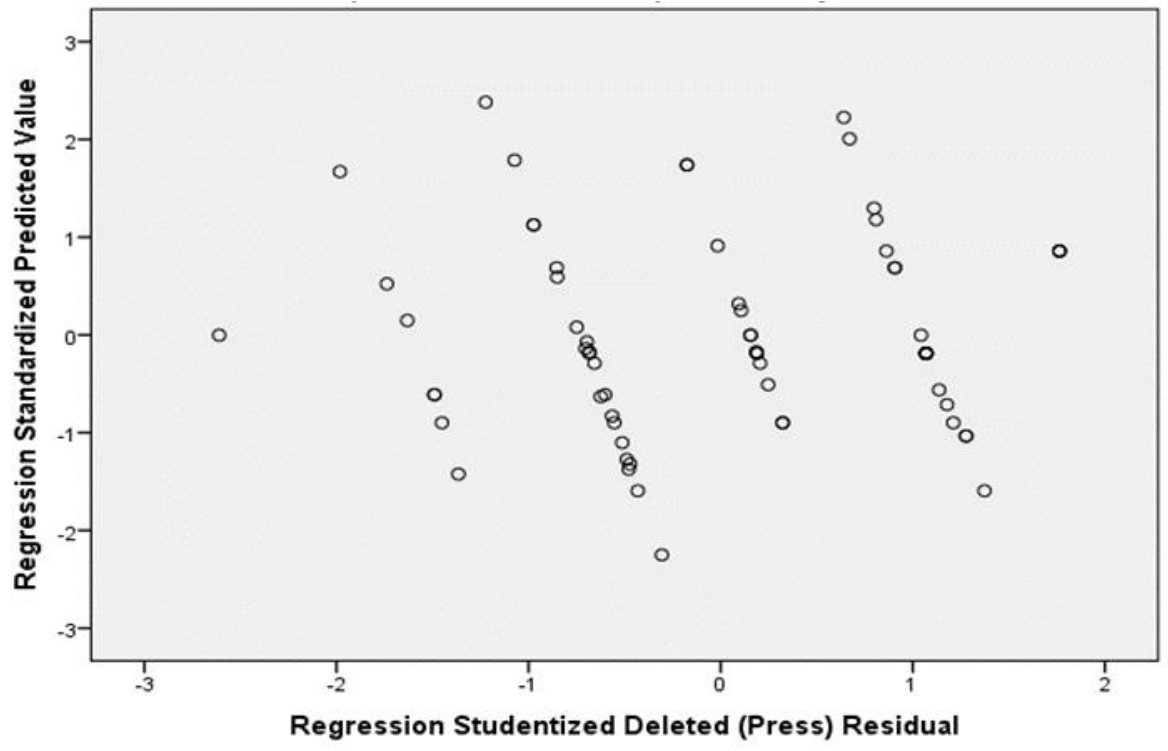

Gambar 3. Uji Heteroskedastisitas

Pada Gambar Uji Heteroskedastisitas tentang grafik scatterplot diatas terlihat titik-titik menyebar secara acak dan tidak membentuk sebuh pola tertentu serta tersebar baik diatas maupun dibawah angka nol pada sumbu y. Hal ini berarti terjadi heteroskedastisitas pada model regresi sehingga model regresi layak dipakai untuk melihat pengaruh variabel independen terhadap variabel dependen.

Analisi Regresi Linier Berganda

Analisis regresi linier berganda digunakan untuk mengukur besarnya pengaruh variabel bebas terhadap variabel terikat dan memprediksi variabel terikat dengan menggunakan variabel bebas. Dalam hal ini untuk mengetahui pengaruh kepemimpinan otoriter, kepemimpinan partisipatif, kepemimpinan delegatif, dan kepemimpinan demokratis terhadap Kinerja Pegawai pada Kantor Dinas Peternakan Aceh. Output dari program IBM SPSS Statistics 22 diperoleh nilai regresi seperti yang tertera pada Tabel koofesien korelasi dan determinasi

Tabel 6. Regresi Coefficients

Coefficients $^{\mathrm{a}}$

\begin{tabular}{|c|c|c|c|c|c|c|c|c|}
\hline \multirow{2}{*}{\multicolumn{2}{|c|}{ Model }} & \multicolumn{2}{|c|}{$\begin{array}{l}\text { Unstandardized } \\
\text { Coefficients }\end{array}$} & \multirow{2}{*}{$\begin{array}{c}\text { Standardized } \\
\text { Coefficients } \\
\text { Beta }\end{array}$} & \multirow[t]{2}{*}{$T$} & \multirow[t]{2}{*}{ Sig. } & \multicolumn{2}{|c|}{ Collinearity Statistics } \\
\hline & & $B$ & Std. Error & & & & Tolerance & VIF \\
\hline & (Constant) & 19.018 & 2.918 & & 6.518 & .000 & & \\
\hline & $\begin{array}{l}\text { Kecerdasan } \\
\text { Emosional }\end{array}$ & .252 & 120 & 157 & 2.863 & .211 & .972 & 1.029 \\
\hline & Kecerdasan Spiritual & 269 & .121 & .070 & 2.569 & .571 & .985 & 1.015 \\
\hline
\end{tabular}

a. Dependent Variable: Kinerja Pegawai

Sumber: data primer yang diolah, 2019

Diperoleh: a

$$
\begin{aligned}
& =19,018 \\
b_{1} & =0,252 \\
b_{2} & =0,269
\end{aligned}
$$

Maka dapat diperoleh model persamaan regresinya adalah :

$$
Y=19,018+0,252+0,147+0,269+e
$$

Berdasarkan hasil analisis regresi linear berganda dapat diketahui bahwa nilai dari a (constant) adalah 6,290. Nilai ini menunjukkan bahwa pada saat Kecerdasan Emosional dan Kecerdasan Spiritual bernilai nol, maka Kinerja Pegawai nilainya sebesar 19,018. Sedangkan nilai dari Kecerdasan Emosional yaitu sebesar 0,252 menunjukkan bahwa ketika terjadi kenaikan Kecerdasan Emosional sebesar satu satuan, maka Kinerja Pegawai akan meningkat sebesar 0,252 satuan, jika nilai dari Kecerdasan Spiritual yaitu sebesar 0,269 menunjukkan bahwa ketika terjadi kenaikan Kecerdasan Spiritual sebesar satu satuan, maka Kinerja Pegawai akan meningkat sebesar 
0,269 satuan. Dengan demikian semakin tinggi nilai variabel Kecerdasan Emosional dan Kecerdasan Spiritual akan semakin signifikan mempengaruhi Kinerja Pegawai pada Kantor Dinas Perhubungan Provinsi Aceh.

\section{Koefisien Korelasi dan Determinasi}

Koefisien korelasi $(R)$ menunjukkan hubungan antara variabel independen dengan variabel dependen. Sedangkan penggunaan adjusted (Adj R2), atau koefisien determinasi yang telah disesuaikan, untuk melihat seberapa jauh kemampuan model dalam menerangkan variasi variabel dependen bila dibandingkan dengan $R$. Berikut ini disajikan hasil uji R2 dapat dilihat Tabel Koofisien Korelasi dan Determinasi dibawah ini

Tabel 7. Koefisien Korelasi dan Determinasi

Model Summaryb

\begin{tabular}{|l|r|r|r|r|r|}
\hline Model & \multicolumn{1}{|c|}{$\mathrm{R}$} & $\mathrm{R}$ Square & \multicolumn{1}{c|}{$\begin{array}{c}\text { Adjusted } \mathrm{R} \\
\text { Square }\end{array}$} & $\begin{array}{c}\text { Std. Error of the } \\
\text { Estimate }\end{array}$ & \multicolumn{2}{|c|}{ Durbin-Watson } \\
\hline 1 & $.684^{\mathrm{a}}$ & .734 & .411 & 1.165 & 1.113 \\
\hline
\end{tabular}

a. Predictors: (Constant), Kecerdasan Spiritual, Kecerdasan Emosional

b. Dependent Variable: Kinerja Pegawai

Sumber: Data primer (diolah) melalui SPSS, 2019

Bedasarkan Tabel koefisien korelasi dan determinasi, maka dapat diketahui nilai koefisien korelasi (R) menunjukkan nilai sebesar 0,684 yang menandakan bahwa hubungan antara variabel independen dengan variabel dependen adalah positif karena memiliki nila $R>0,5$. Adapun nilai $R 2$ sebesar 0,734 menunjukkan bahwa hanya sebesar $73,4 \%$ variasi variabel dependen (Kinerja Pegawai) yang dapat dijelaskan oleh variasi variabel independen (Kecerdasan Emosional dan Kecerdasan Spiritual) dalam penelitian ini. Sedangkan sisanya yang sebesar $26,6 \%$ dijelaskan oleh variabel lain yang tidak dimasukkan ke dalam penelitian yang mungkin dapat mempengaruhi Kinerja Pegawai.

\section{Uji Hipotesis}

Analisis ini digunakan untuk menguji ada tidaknya pengaruh variabel independen terhadap variabel dependen secara simultan atau parsial. Hipotesis dalam pengujian ini adalah.

Tabel 8. Uji Hipotesis

\begin{tabular}{|c|c|c|c|c|}
\hline \multirow{2}{*}{\multicolumn{2}{|c|}{ Bentuk Pengujian }} & \multicolumn{2}{|c|}{ Nilai Statistik } & \multirow{2}{*}{ Keterangan } \\
\hline & & F Hitung & F Tabel & \\
\hline \multicolumn{2}{|c|}{ Pengujian secara simultan } & 5,752 & 2,352 & Hipotesis diterima \\
\hline \multicolumn{2}{|c|}{ Pengujian secara parsial } & t hitung & t tabel & \\
\hline $\begin{array}{l}1 \\
2\end{array}$ & $\begin{array}{l}\text { Kecerdasan Emosional } \\
\text { Kecerdasan Spiritual }\end{array}$ & $\begin{array}{l}2,863 \\
2,569\end{array}$ & $\begin{array}{l}1,995 \\
1,995\end{array}$ & $\begin{array}{l}\text { Hipotesis diterima } \\
\text { Hipotesis diterima }\end{array}$ \\
\hline
\end{tabular}

Sumber: data primer yang diolah, 2019

Hasil perhitungan uji hipotesis ( lihat lampiran ) yang disajikan pada tabel 4.12 mempunyai makna dan diinterprestasikan sebagai berikut :

1. Secara simultan variabel Kecerdasan Emosional dan Kecerdasan Spiritual berpengaruh signifika terhadap Kinerja Pegawai pada kantor Dinas Perhubungan Provinsi Aceh, karena hasil pengujian statistik yang didapat menunjukkan nilai $F$ hitung sebesar 5,752 lebih besar dari $F$ tabel sebesar 2,352. Dengan demikian berdasarkan probabilitas/signifikan disimpulkan bahwa: $\mathrm{Ha}=$ diterima dan $\mathrm{Ho}=$ ditolak. Dapat disimpulkan bahwa hipotesis yang diajukan yaitu diduga Kecerdasan Emosional dan Kecerdasan Spiritual mempunyai hubungan positif dengan Kinerja Pegawai terbukti kebenarannya.

2. Secara parsial variabel Kecerdasan Emosional berpengaruh signifikan terhadap Kinerja Pegawai pada kantor Dinas Perhubungan Provinsi Aceh, karena hasil pengujian statistik yang didapat menunjukkan nilai thitung sebesar 2,863lebih besar dari ttabel sebesar 1,995. Dengan demikian berdasarkan probabilitas/signifikan disimpulkan bahwa: $\mathrm{Ha}=$ diterima dan $\mathrm{Ho}=$ ditolak. Dapat disimpulkan bahwa hipotesis yang diajukan yaitu diduga Kecerdasan Emosional mempunyai hubungan positif dengan Kinerja Pegawai terbukti kebenarannya.

3. Secara parsial variabel Kecerdasan Spiritual berpengaruh signifikan terhadap Kinerja Pegawai pada kantor Dinas Perhubungan Provinsi Aceh, karena hasil pengujian statistik yang didapat menunjukkan nilai thitung sebesar 2,569lebih besar dari ttabel sebesar 1,995. Dengan demikian berdasarkan probabilitas/signifikan 
disimpulkan bahwa: $\mathrm{Ha}=$ diterima dan $\mathrm{Ho}=$ ditolak. Dapat disimpulkan bahwa hipotesis yang diajukan yaitu diduga Kecerdasan Spiritual mempunyai hubungan positif dengan Kinerja Pegawai terbukti kebenarannya.

\section{Pembahasan}

Berdasarkan hasil analisis regresi linear berganda dapat diketahui bahwa nilai dari a (constant) adalah 6,290. Nilai ini menunjukkan bahwa pada saat Kecerdasan Emosional dan Kecerdasan Spiritual bernilai nol, maka Kinerja Pegawai nilainya sebesar 19,018. Sedangkan nilai dari Kecerdasan Emosional yaitu sebesar 0,252 menunjukkan bahwa ketika terjadi kenaikan Kecerdasan Emosional sebesar satu satuan, maka Kinerja Pegawai akan meningkat sebesar 0,252 satuan, jika nilai dari Kecerdasan Spiritual yaitu sebesar 0,269 menunjukkan bahwa ketika terjadi kenaikan Kecerdasan Spiritual sebesar satu satuan, maka Kinerja Pegawai akan meningkat sebesar 0,269 satuan. Dengan demikian semakin tinggi nilai variabel Kecerdasan Emosional, Kecerdasan Intelektual dan Kecerdasan Spiritual akan semakin signifikan mempengaruhi Kinerja Pegawai pada Kantor Dinas Perhubungan Provinsi Aceh.

Secara simultan variabel Kecerdasan Emosional dan Kecerdasan Spiritual berpengaruh signifika terhadap Kinerja Pegawai pada kantor Dinas Perhubungan Provinsi Aceh, karena hasil pengujian statistik yang didapat menunjukkan nilai $F$ hitung sebesar 5,752 lebih besar dari Ftabel sebesar 2,352. Dengan demikian berdasarkan probabilitas/signifikan disimpulkan bahwa: $\mathrm{Ha}=$ diterima dan $\mathrm{Ho}=$ ditolak. Dapat disimpulkan bahwa hipotesis yang diajukan yaitu diduga Kecerdasan Emosional dan Kecerdasan Spiritual mempunyai hubungan positif dengan Kinerja Pegawai terbukti kebenarannya.

Secara parsial variabel (X1) Kecerdasan Emosional berpengaruh signifikan terhadap Kinerja Pegawai pada kantor Dinas Perhubungan Provinsi Aceh, karena hasil pengujian statistik yang didapat menunjukkan nilai thitung sebesar 2,863lebih besar dari ttabel sebesar 1,995. Dengan demikian berdasarkan probabilitas/signifikan disimpulkan bahwa: $\mathrm{Ha}=$ diterima dan $\mathrm{Ho}=$ ditolak. Dapat disimpulkan bahwa hipotesis yang diajukan yaitu diduga Kecerdasan Emosional mempunyai hubungan positif dengan Kinerja Pegawai terbukti kebenarannya.

Secara parsial variable (X2) Kecerdasan Spiritual berpengaruh signifikan terhadap Kinerja Pegawai pada kantor Dinas Perhubungan Provinsi Aceh, karena hasil pengujian statistik yang didapat menunjukkan nilai thitung sebesar 2,569lebih besar dari ttabel sebesar 1,995. Dengan demikian berdasarkan probabilitas/signifikan disimpulkan bahwa: $\mathrm{Ha}=$ diterima dan $\mathrm{Ho}=$ ditolak. Dapat disimpulkan bahwa hipotesis yang diajukan yaitu diduga Kecerdasan Spiritual mempunyai hubungan positif dengan Kinerja Pegawai terbukti kebenarannya.

Nilai koefisien korelasi $(R)$ menunjukkan nilai sebesar 0,684 yang menandakan bahwa hubungan antara variabel independen dengan variabel dependen adalah positif karena memiliki nila $R>0,5$. Adapun nilai $R 2$ sebesar 0,734 menunjukkan bahwa hanya sebesar $73,4 \%$ variasi variabel dependen (Kinerja Pegawai) yang dapat dijelaskan oleh variasi variabel independen (Kecerdasan Emosional dan Kecerdasan Spiritual) dalam penelitian ini. Sedangkan sisanya yang sebesar $26,6 \%$ dijelaskan oleh variabel lain yang tidak dimasukkan ke dalam penelitian yang mungkin dapat mempengaruhi Kinerja Pegawai.

\section{KESIMPULAN DAN SARAN}

Berdasarkan hasil analisis yang telah dilakukan dalam penelitian ini dapat disimpulkan sebagai berikut:

1. Kecerdasan Emosional dan Kecerdasan Spritual secara simultan berpengaruh signifika terhadap kinerja pegawai pada kantor Dinas Perhubungan Provinsi Aceh,hal ini disebabkan hasil pengujian statistik yang didapat menunjukkan nilai $F$ hitung sebesar 5,752 lebih besar dari $F$ tabel sebesar 2,352, maka berdasarkan probabilitas/signifikan disimpulkan bahwa: $\mathrm{Ha}=$ diterima dan $\mathrm{Ho}=$ ditolak.

2. Kecerdasan Emosional ( Variabel X1) secara parsial berpengaruh signifikan terhadap kinerja pegawai pada kantor Dinas Perhubungan Provinsi Aceh, karena hasil pengujian statistik yang didapat menunjukkan nilai thitung sebesar 2,863lebih besar dari ttabel sebesar 1,995, maka probabilitas/signifikan disimpulkan bahwa: $\mathrm{Ha}=$ diterima dan $\mathrm{Ho}=$ ditolak.

3. Kecerdasan Spritual ( Variabel X2 ) secara parsial berpengaruh signifikan terhadap kinerja pegawai pada kantor Dinas Perhubungan Provinsi Aceh, karena hasil pengujian statistik yang didapat menunjukkan nilai thitung sebesar 2,569lebih besar dari ttabel sebesar 1,995. Dengan demikian berdasarkan probabilitas/signifikan disimpulkan bahwa: $\mathrm{Ha}=$ diterima dan $\mathrm{Ho}=$ ditolak.

4. Hubungan antara variable independen dengan variable Dependen menunjukkan nilai koefisien korelasi (R) sebesar 0,684 yang artinya memiliki hubungan yang positif karena nila $R>0,5$.

5. Nilai R2 sebesar 0,734 menunjukkan bahwa hanya sebesar $73,4 \%$ variasi variabel dependen (kinerja pegawai) yang dapat dijelaskan oleh variasi variabel independen (kecerdasan emosional dan kecerdasan 
spiritual) dalam penelitian ini. Sedangkan sisanya yang sebesar $26,6 \%$ dijelaskan oleh variabel lain yang tidak dimasukkan ke dalam penelitian yang mungkin dapat mempengaruhi kinerja pegawai

\section{Saran}

Berdasarkan hasil penelitian maka peneliti ingin menyampaikan saran kepada kantor Dinas Perhubungan Provinsi Aceh sebagai berikut:

1. Penelitian selanjutnya disarankan agar peneliti dapat menambah variabel faktor kecerdasan intelektual (IQ) atau factor lainnya yang paling berpengaruh terhadap kinerja pegawai, kemudian juga perlu dilakukan penelitian ulang untuk mengetahui peningkatan kinerja pegawai setelah memperbaiki pelaksanaan kecerdasan emosional dan kecerdasan spiritual yang baik.

2. Pimpinan Kantor Dinas Perhubungan Provinsi Aceh perlu terus melaksanakan/merealisasikan Visi, misi dan tujuan yang sudah ditetapkan dari kantor impinan kantor Dinas Perhubungan Provinsi Aceh. Salah satu faktor yag dianggap penting bagi peningkatan kinerja pegawai yaitu kecerdasan emosional (emotional quotient) yang merupakan sisi lain dari kecerdasan yang dimiliki pegawai yang dianggap berperan penting dalam menentukan tingkat kesuksesan pegawai dalam mencapai tujuan instansi.

3. Meningkatkan kemampuan seoarang pegawai dengan kemampuan kecerdasan emosional tinggi agar mampu mengenal dirinya sendiri, mampu berpikir rasional dan berperilaku positif serta mampu menjalin hubungan sosial yang baik karena didasari pemahaman emosi orang lain.

4. Meningkatkan kecerdasan spiritual pegawai karena mempunyai peranan penting dalam memberikan pelayanan kepada masyarakat agar masyarakat akan mampu menilai bahwa tindakan pegawai lebih bemakna, sehingga akan menghasilkan kinerja pegawai yang tinggi.

\section{REFERENSI}

[1] Amir, Saddam. 2013. Pengaruh Kecerdasan Emosional (EQ) dan Kecerdasan Spiritual (SQ) Terhadap Kinerja Karyawan. Skripsi. Universitas Islam Negeri Maulana Malik Ibrahim: Malang.

[2] Agustian, Ary Ginanjar. 2010. Rahasia Sukses Membangun Kecerdasan Emosi dan Spiritual. Jakarta: Arga.

[3] Dessler. 2010. Pengaruh Keterikatan Karyawan (Mployee engagement) Terhadap Kinerja Kryawan. Palembang: PT. Badja Baru

[4] Ghassani, Radya. 2018. Pengaruh Kecerdasan Emosional (EQ), Kecerdasan Intelektual (IQ), Dan Kecerdasan Spiritual (SQ) terhadap Kinerja Pegawai Di Sekretariat DPRD Provinsi Riau. Skripsi. Universitas Islam Negeri Sunan Kalijaga. Jogyakarta.

[5] Ghozali. 2011, Aplikasi Analisis Multivariate Dengan Program IBM SPSS 19. Semarang: Badan Penerbit Universitas Diponegoro.

[6] Goleman, D. 2014. Emitional Intelligence. Kecerdasan Emosional Mengapa El Lebih Penting daripada IQ. (Terjemahan T. Hermaya). Jakata : PT Gramedia Pustaka Utama.

[7] Hawari. 2014. Psikometri Alat Ukur (Skala) Kesehatan Jiwa. Jakarta: Balai Penerbit FKUI.

[8] Mahmudah. 2015. Filsafat Eksistensialisme: Telaah Ajaran Dan Relevansinya Dengan Tujuan Pendidikan Di Indonesia. Insania, 14 (3), 336-447.

[9] Mangkunegara, A.A. Anwar Prabu. 2013. Manajemen Sumber Daya Manusia Perusahaan. Bandung: PT Remaja Rosdakarya.

[10] Notoatmodjo. 2010. Metodelogi Penelitian Kesehatan. Jakarta: Rineka Cipta.

[11] Paisal, dkk. 2010. Pengaruh Kecerdasan Emosional Dan Kecerdasan Spiritual Terhadap Kinerja Karyawan. Palembang Jurnal IImiah Orasi Bisnis. ISSN: 2085-1375 Edisi Ke-IV. Nopember 2010.

[12] Priyatno, Duwi. 2012. Cara Kilat Belajar Analisis Data dengan SPSS 20. Andi Offset: Yogyakarta.

[13] Ramayulis dan Samsul Nizar. 2014. Filsafat Pendidikan Islam: Telaah Sistem Pendidikan dan Pemikiran Para Tokohnya. Jakarta: Kalam Mulia.

[14] Robbins dan Judge. 2013. Perilaku Organisasi, Edisi Duabelas. Penerbit Salemba Empat: Jakarta.

[15] Rangkuti. 2011. SWOT Balanced Scorecard. Jakarta: PT. Gramedia Pustaka Utama. 
[16] Rosdaranita, Alifah, Diana. 2017. Pengaruh Kecerdasan Spiritual dan Kecerdasan Emosional terhadap Kinerja Karyawan di CV. Sidiq Manajemen Yogyakarta.Skripsi. Universitas Islam Negeri Sunan Kalijaga: Yogyakarta.

[17] Simanjuntak, J. Payaman. 2015. Manajemen \& Evaluasi Kinerja. Jakarta: FEUI.

[18] Stein, S.J dan Book, H.E. 2013. Ledakan EQ. Limabelas Prinsip Dasar Kecerdasan Emosi Meraih Sukses (Terjemahan Trinanda Riani Januarsari dan Yudhi Murtanto). Bandung: Kaiffa

[19] Sugiyono. 2012. Metode Penelitian Kunatitatif Kualitatif dan R\&D. Alfabeta: Bandung.

[20] Sobandi. 2014. Perilaku Kewargaan Organisasi (Organizational Citizeship Behavior )Sebagai Faktor Yang Mempengaruhi Kinerja Pegawai. Manajerial: Jurnal Manajemen dan Sistem Informasi.

[21] Santoso. 2014. Studi Deskriftif Effect Size Penelitian-Penelitian. di Fakultas Psikologi Universitas Sanata Dharma, Yogyakarta: Juranal Penelitian.

[22] Sarboini, 2016 Performance of Employees and Impect On Promotion Of Position, Jurnal IImiah Peuradeun Vol 4, No 1, Januari 2016 Hal ( 103 - 113)

[23] Subudi Made (2015) Tentang: Pengaruh Kompetensi Dan Kecerdasan Emosional Terhadap Kinerja Karyawan.Si Doi Hotel Dan Restaurant Legian.

[24] Suharsono. 2014. Melejitkan IQ, IE \& IS. Jakarta: Inisiasi Pess.

[25] Taufik. 2015. Empati: Pendekatan Psikologi Sosial. Jakarta: Raja Grafindo.

[26] Triana (2013) tentang: Pengaruh Kecerdasan Emosional, Komitmen Organisasional Dan Organizational Citizenship Behavior Terhadap Kinerja Karyawan. Skripsi. Universitas Mulawarman: Kalimantan Timur

[27] Widodo. 2013. Manajemen Pengembangan Sumber Daya Manusia. Yogyakarta: Pustaka Pelajar. 